\title{
Modeling Carbon Sequestration in Home Lawns
}

\author{
Gina Zirkle ${ }^{1}$ \\ Carbon Management and Sequestration Center, The Ohio State University, \\ 210 Kottman Hall, 2021 Coffey Road, Columbus OH 43210
}

\section{Rattan Lal \\ Carbon Management and Sequestration Center, The Ohio State University, Columbus, OH 43210}

\section{Bruce Augustin}

The Scotts Miracle-Gro Company, Marysville OH 43041

Additional index words. soil C sequestration, global warming, lawn management, turfgrass, hidden $\mathrm{C}$ costs

\begin{abstract}
Soil organic carbon (SOC) sequestration and the impact of carbon (C) cycling in urban soils are themes of increasing interest. A model was developed to investigate the potential of $\mathrm{C}$ sequestration in home lawns. The model contrasted gross $\mathrm{C}$ sequestered versus the hidden $\mathrm{C}$ costs (HCC) associated with typical lawn maintenance practices. The potential of SOC sequestration for U.S. home lawns was determined from SOC sequestration rates of turfgrass and grasslands. Net SOC sequestration in lawn soils was estimated using a simple mass balance model derived from typical homeowner lawn maintenance practices. The average SOC sequestration rate for U.S. lawns was 46.0 to $127.1 \mathrm{~g} \mathrm{C} / \mathrm{m}^{2} /$ year. Additional $\mathrm{C}$ sequestration can result from biomass gains attributable to fertilizer and irrigation management. Hidden $C$ costs are the amount of energy expended by typical lawn management practices in grams of carbon equivalents $(\mathrm{CE}) / \mathrm{m}^{2} /$ year and include practices including mowing, irrigating, fertilizing, and using pesticides. The net SOC sequestration rate was assessed by subtracting the HCC from gross SOC sequestration rate. Lawn maintenance practices ranged from low to high management. Low management with minimal input (MI) included mowing only, a net SOC sequestration rate of 25.4 to $114.2 \mathrm{~g} \mathrm{C} / \mathrm{m}^{2} /$ year. The rate of $\mathrm{SOC}$ sequestration for doit-yourself (DIY) management by homeowners was 80.6 to $183.0 \mathrm{~g} \mathrm{C} / \mathrm{m}^{2} / \mathrm{year}$. High management, based on university and industry-standard best management recommendation practices (BMPs), had a net SOC sequestration rate of 51.7 to $204.3 \mathrm{~g} \mathrm{C} / \mathrm{m}^{2} / \mathrm{year}$. Lawns can be a net sink for atmospheric $\mathrm{CO}_{2}$ under all three evaluated levels of management practices with a national technical potential ranging from 25.4 to 204.3 g C/m²/year.
\end{abstract}

Research on abrupt climate change and the $\mathrm{C}$ cycle have become major thematic foci since the 1990s. SOC sequestration is one of the strategies proposed to stabilize atmospheric carbon dioxide $\left(\mathrm{CO}_{2}\right)$ (Lal, 2004a; Smith et al., 2007b). The interest in urban soils is derived from the fact that $75 \%$ of the U.S. population lives in urban areas where individuals can potentially affect $\mathrm{C}$ sequestration in their home landscape (United States Census Bureau, 2010). Lawn grasses are the predominant plants in the urban landscape that are managed by the homeowner (Beard, 1973). A simple C footprint benchmark of home lawns can be developed from three components: the capacity of urban soils to store $\mathrm{C}$, the capability of grass plants to fix and sequester $\mathrm{C}$, and the $\mathrm{C}$ footprint of lawn maintenance practices.

Received for publication 11 Nov. 2010. Accepted for publication 4 Mar. 2011.

${ }^{1}$ To whom reprint requests should be addressed; e-mail gina.zirkle@gmail.com.
Several studies have evaluated $\mathrm{C}$ sequestration potential of agricultural and urban soils as one of several options to stabilize atmospheric $\mathrm{CO}_{2}$ abundance (Blanco-Canqui and Lal, 2004; Bruce et al., 1999; Lal, 2004a, 2008; Leified, 2006; Pataki et al., 2006; Pickett et al., 2008; Pouyat et al., 2002, 2006; Smith et al., 1993). SOC is comprised of the historic accumulation of humus in the soil. Long-term storage of SOC occurs when humus reaches a point of stability and gains exceed losses (Whitehead and Tinsley, 2006). Variations in the SOC pool occur in different ecosystems because of differences in the rate of soil organic matter decay through microbial decomposition, temperature fluctuations, and precipitation amounts and frequencies (Pouyat et al., 2002).

The SOC pool is important for soil structure maintenance and other ecosystem services (Lal, 2004a, 2009). It improves numerous soil properties and processes including soil tilth, aggregation, plant-available water and nutrient capacities, reduction in susceptibility to erosion, and filtering of pollutants (Blanco-Canqui and Lal, 2004). Soil organic carbon is depleted through soil cultivation and land use conversion (Lal, 2004a; Post and Kwon, 2000) and can be enhanced through those soil conservation and restoration practices, which add biomass $\mathrm{C}$ and influence the rate of its decomposition (Lal, 2004a). Common conservation and restoration practices include no-till (NT) agriculture, perennial plant cover, fertilization, irrigation, and organic amendments (Lal, 2004a; Post and Kwon, 2000; Post et al., 2004). Moreover, lawn grasses are a perennial plant cover and have the potential for longterm SOC sequestration (Pataki et al., 2006; Pouyat et al., 2006).

Urban lawns are potential $\mathrm{C}$ sinks and their prevalence in urban landscapes suggests that they can store a significant amount of $\mathrm{C}$ (Pataki et al., 2006; Pouyat et al., 2002, 2006). Urbanized land covers $\approx 40.6$ million hectares (Mha) in the United States (United Nations, 2004a). The National Census Bureau estimates that $75 \%$ to $80 \%$ of North American population lives in urban areas (United Nations 2004b). Urban land use is $3.5 \%$ to $4.9 \%$ of the U.S. land area (National Association of Realtors, 2001; Nowak et al., 2001). As urbanization increases, the percentage of land converted into turfgrass is also increasing (Bandaranayake et al., 2003; Lorenz and Lal, 2009a; Milesi et al., 2005; Qian and Follett, 2002).

Approximately $41 \%$ of the U.S. urban area is under residential land use (Nowak et al., 1996, 2001). Turfgrasses cover 16 to 20 Mha in the United States, which includes residential, commercial, and institutional lawns; parks; golf courses; and athletic fields (Grounds Maintenance, 1996; Milesi et al., 2005). There are 80 million U.S. single-family detached homes with 6.4 Mha under lawns (Augustin, 2007; National Association of Realtors, 2001; National Gardening Association, 2004). The size of home lawns varies regionally (north to south and east to west) as well as locally (rural versus suburban). Home lot size differs from that of home lawn size (National Association of Realtors, 2001). Home lot size includes the house and land owned by the homeowners, where home lawn size includes the area covered by turfgrass. In this study, the average size of household lawns in the United States is 0.08 ha (Augustin, 2007; National Association of Realtors, 2001; Vinlove and Torla, 1995).

The estimated SOC pool in the U.S. urban soils is $77.0 \pm 2.0 \mathrm{Mg} \cdot \mathrm{ha}^{-1}$ (Pouyat et al., 2006). A compilation of research showing conversion of crop land into perennial grasses sequestered an average of $0.3 \mathrm{Mg} \mathrm{C} /$ ha/year (Post and Kwon, 2000), and the rate can be as high as $1.1 \mathrm{Mg} \mathrm{C} / \mathrm{ha} /$ year with fertilizer and irrigation management (Contant et al., 2001; Gebhart et al., 1994; Qian and Follett, 2002). Qian and Follett (2002) modeled SOC sequestration with historic soil testing data from golf courses and reported that soils under golf course sequester SOC at a rate of $1.0 \mathrm{Mg} \mathrm{C} /$ ha/year. Land under the Conservation Reserve Program also sequesters SOC at a similar rate (Qian and Follett, 2002). Ohio farmland converted to golf courses sequesters SOC at an initial rate of 2.5 to $3.6 \mathrm{Mg} \mathrm{C} / \mathrm{ha} /$ year as a result 
of permanent groundcover and increased management inputs of fertilizer and irrigation (Selhorst, 2007).

Although home lawns have potential to sequester $C$, information on SOC dynamics in urban lawns is limited (Pouyat et al., 2006), yet the technical potential for urban lawns to sequester SOC is high as a result of perennial turfgrass cover and improved management. Lawns provide a perennial groundcover and the soils beneath established grasses are relatively undisturbed. Therefore, the lawn ecosystem has been compared with perennial grasslands and NT agricultural systems (Falk, 1976, 1980; Follett et al., 2009; Qian and Follett, 2002). Lawns have the capacity to produce biomass at a rate similar to those of managed crops such as corn (Zea mays), wheat (Triticum aestuvum), and prairie grasses (Falk, 1976, 1980; Qian and Follett, 2002). A complete turfgrass $\mathrm{C}$ cycle accounting for turfgrass maintenance practices of mowing, irrigating, fertilizing, and applying pesticides must be completed to determine net $\mathrm{C}$ sequestration rates (Bandaranayake et al., 2003; Pickett et al., 2008; Pouyat et al., 2006).

In general, fertilizer and irrigation practices can increase the rate of SOC sequestration (Campbell and Zenter, 1993; Glendining and Powlson, 1991; Gregorich et al., 1996; Lal, 2003; Paustian et al., 1997). Thus, use of fertilizers and irrigation as lawn maintenance practices could increase plant biomass and enhance the SOC pool. An increase in input of plant biomass also increases the rate of humification (Duiker and Lal, 2000; Puget et al., 2005).

A wide range of techniques exist for estimating the technical potential of SOC sequestration (Bruce et al., 1999; Rickman et al., 2001; Smith et al., 1993, 2008). Changes in the SOC pool can be measured directly over time (Bruce et al., 1999). Direct measurements are an efficient technique for a small scale (plot scale) but can be complicated by spatial and temporal differences in soils for large regional scales (Bruce et al., 1999; Qian et al., 2003; Smith et al., 1993). Mathematical modeling of SOC is well developed and is widely used to study SOC dynamics under a range of environmental conditions at regional scales (Bruce et al., 1999; Lal, 2004a; Post et al., 2004; Qian et al., 2003; Smith et al., 1993, 2008). Modeling has been used extensively to estimate changes in the SOC pool resulting from management practices (Blanco-Canqui and Lal, 2004; Bruce et al., 1999; Lal, 2004a, 2004b).

Although atmospheric enrichment of $\mathrm{CO}_{2}$ is cited as a principal driver of climate change, $\mathrm{N}_{2} \mathrm{O}$ and $\mathrm{CH}_{4}$ are other green house gases (GHGs) of concern. The global warming potential (GWP) of $\mathrm{N}_{2} \mathrm{O}$ and $\mathrm{CH}_{4}$ can be expressed in terms of $\mathrm{CO}_{2}-\mathrm{C}$ equivalents by knowing their radiative forcing and residence time. Radiative forcing is the difference in the amount of radiation energy entering and exiting the earth's atmosphere. On a 100-year time scale, one unit of $\mathrm{N}_{2} \mathrm{O}$ has the same GWP as 310 units of $\mathrm{CO}_{2}$ and one unit of $\mathrm{CH}_{4}$ has the same GWP as 21 units of $\mathrm{CO}_{2}$ (Intergovernmental Panel on Climate Change, 2001).
Soil emissions of $\mathrm{CO}_{2}$, methane $\left(\mathrm{CH}_{4}\right)$, and nitrous oxide $\left(\mathrm{N}_{2} \mathrm{O}\right)$ are highly impacted by soil properties and climate (Kaye et al., 2005; Khan et al., 2007; Maggiotto et al., 2000; Smith et al., 2007a). Carbon dioxide represents over $98 \%$ of the soil GHG flux and is accounted for by NPP estimates in the basic model (Phillips et al., 2009). Emissions of $\mathrm{CH}_{4}$ are formed from anaerobic fermentation of organic matter under conditions typical of flooded rice paddies but not of typical home lawn ecosystem conditions. Normal well-drained soils tend to act as a sink for $\mathrm{CH}_{4}$ (Janssen et al., 2009; Phillips et al., 2009). Soil emissions of $\mathrm{N}_{2} \mathrm{O}$ are less than $1 \%$ of the GHG soil flux and result from soil microbial activity (Kaye et al., 2005; Phillips et al., 2009). Soil $\mathrm{N}_{2} \mathrm{O}$ emissions are increased under saturated soil conditions (Eichner, 1990; Smith et al., 2007a). Average soil $\mathrm{N}_{2} \mathrm{O}$ flux is comprised of $65 \%$ to $77 \%$ background emissions and $23 \%$ to $35 \%$ fertilizer-induced emissions (Snyder et al., 2007). Significant potential exists for the mitigation of these GHG fluxes from soils by management practices according to the Intergovernmental Panel on Climate Change (Smith et al., 2007b).

Determining $\mathrm{N}$ losses from turfgrass and soil ecosystems is a useful strategy for developing an appropriate fertilization program that promotes healthy turfgrass as well as addressing the environmental concerns associated with $\mathrm{N}$ losses. Losses of $\mathrm{N}$ from turfgrass occur through denitrification, leaching, volatilization, runoff, and in some cases by erosion (Baird et al., 2000; Foth and Ellis, 1997; Petrovic, 1990; Tinsdale et al., 1985).

Groffman et al. (2009) reported few differences in $\mathrm{N}_{2} \mathrm{O}$ fluxes above four urban grassland and eight forested ecosystems. The flux of $\mathrm{N}_{2} \mathrm{O}$ from intensively fertilized grasslands did not exceed that from forest ecosystems, indicating that $\mathrm{N}$ cycling in urban lands is a complex process. The data by Groffman and colleagues also suggests that $\mathrm{N}$ retention may be significant in these ecosystems. Denitrification losses are most likely low for many turfgrass/soil conditions (Carrow et al., 2001). Some conditions such as soils compacted with poor drainage and algae covered surfaces may be conducive to denitrification. Kaye et al. (2004) studied the fluxes of $\mathrm{CH}_{4}$ and $\mathrm{N}_{2} \mathrm{O}$ from urban soils and compared these with those from non-urban ecosystems.

The ecosystems studied consisted of urban lawn, native shortgrass steppe, dryland wheat fallow, and flood-irrigated corn. The urban lawn fluxes of $\mathrm{CH}_{4}$ and $\mathrm{N}_{2} \mathrm{O}$ were comparable to those from irrigated corn (Zea mays) but were more than those from wheat (Triticum aestivum) fallow or native grasslands. Limited information is available for field comparisons of soil-atmosphere exchange on $\mathrm{N}_{2} \mathrm{O}$ and $\mathrm{CH}_{4}$ fluxes from turfgrass/soil ecosystems.

Although this model did not account for $\mathrm{CH}_{4}$ and $\mathrm{N}_{2} \mathrm{O}$, future modeling scenarios should consider inclusion of soil GHG when dictated by specific climate, soil conditions, or management practices known to greatly influence GHG fluxes (Groffman et al., 2009; Lorenz and Lal, 2009b; Neeta et al., 2008; Raciti et al., 2008).
The objective of this research was to investigate a simple mass balance model that compares the rate of SOC sequestration under a range of management scenarios for singlefamily home lawns practiced in diverse ecoregions of the United States. This article specifically explains methods to estimate the net pool of SOC sequestration under MI, medium input determined as DIY homes based on average current practices, and high input determined as homes using BMPs. Net SOC sequestration rates of each category were determined by subtracting the HCC from gross SOC sequestration.

\section{Materials and Methods}

Soil organic carbon sequestration rates for U.S. home lawns were modeled using data available from published literature. All data for SOC sequestration rates were compiled for the $0-$ to $15-\mathrm{cm}$ soil layer. The net SOC sequestration rate was the amount of gross $\mathrm{C}$ accumulated minus the HCC of lawn maintenance practices expressed as $\mathrm{C}$ equivalents.

Home lawns are cared with a number of agronomic and maintenance inputs with the majority including mowing, use of fertilizers and pesticides, and irrigation. Forty million home lawns use a MI system (mowing only), 30 million lawns are maintained by the homeowner, and 10 million use a lawn care service or apply fertilizer multiple times a year (Augustin, 2007)

Do-It-Yourself lawn practices focus on average current lawn maintenance practices to calculate average net SOC sequestration rate in U.S. home lawns. Estimates of lawn maintenance practices for MI and BMPs are calculated to benchmark $\mathrm{C}$ sequestration of low- to highrange lawn maintenance regimes. These ranges also provide an estimate of lawn management practices under a wide range of regional environmental conditions. The parameters, data, and assumptions used in the model are summarized in Table 1. This equation is expressed in units of $\mathrm{g} / \mathrm{m}^{2} /$ year (Eq. [1]).

Net $\mathrm{C}$ sequestration rate $=$ Gross $\mathrm{SOC}$
sequestration rate $-\mathrm{HCC}$

Soil organic carbon sequestration. The net rates of SOC sequestration were compiled from published literature on NPP and SOC dynamics (Tables 2 and 3). Data on net primary productivity (NPP) were used to estimate the average rate of SOC sequestration after the humification of plant material (Smith et al., 1993). The only data sets selected for use in this study consisted of gross primary productivity minus the respiration using both the belowground (root) and aboveground (shoot) growth rate for U.S. grasslands and turfgrasses (Table 2). The grassland sites ranged widely in geography and climate across the United States. The NPP data used in this model included direct measurements of dry plant biomass over 12 different sites. The average range of NPP was 5.89 to $12.71 \mathrm{Mg}$ dry matter/ha/year. Each year, $\approx 10 \%$ of the biomass added to the soil may be humified (Duiker and Lal, 2000, 
Table 1. Summary of parameters, data, and assumptions used in the model development.

\begin{tabular}{|c|c|c|c|c|c|}
\hline $\begin{array}{l}\text { Lawns } \\
\text { category }\end{array}$ & $\begin{array}{l}\text { No. of lawns } \\
\text { (millions) }\end{array}$ & Mowings/year & $\begin{array}{l}\text { No. of irrigated } \\
\text { lawns (millions) }\end{array}$ & Fertilizer use & Pesticide use \\
\hline$\overline{\mathrm{MI}}$ & 40 & 28 & None & None & None \\
\hline DIY & 30 & 28 & $\begin{array}{c}3-4.5 \\
(10 \% \text { to } 15 \%)\end{array}$ & $\begin{array}{l}9.07 \times 10^{5} \mathrm{Mg} \text { fertilizer sold/year } \\
(\text { The Scotts Miracle-Gro } \\
\text { Company, 2006) } \\
2.63 \times 10^{5} \text { nitrogen } \\
2.70 \times 10^{4} \text { phosphorus } \\
3.60 \times 10^{4} \text { potassium }\end{array}$ & $\begin{array}{l}\text { EPA reported pesticide use estimations } \\
\text { in } \mathrm{Mg} \text { /year (United States } \\
\text { Environmental Protection } \\
\text { Agency, 2004) } \\
5.9 \times 10^{3} \mathrm{Mg} \text { herbicide } \\
1.4 \times 10^{3} \mathrm{Mg} \text { insecticide }\end{array}$ \\
\hline BMPs & 10 & 28 & 10 & $\begin{array}{l}\text { Industry-standard recommendations } \\
\text { in } \mathrm{kg} / \mathrm{ha} / \text { year } \\
147-250 \text { nitrogen } \\
30-50 \text { phosphorus } \\
60-100 \text { potassium }\end{array}$ & $\begin{array}{l}\text { Industry-standard recommendations } \\
\text { in } \mathrm{kg} / \mathrm{ha} / \text { year } \\
1 \text { pre-emergent herbicide at } 1.77 \\
1 \text { post-emergence herbicide } \\
\text { combo at } 2.54 \\
1 \text { insect control at } 0.09\end{array}$ \\
\hline
\end{tabular}

$\mathrm{MI}=$ minimal input; DIY = do-it-yourself; BMPs = best management practices.

Table 2. Annual net primary productivity of dry plant weight (roots and shoots) of grasslands in the United States.

\begin{tabular}{lcl}
\hline Biomass/region & $\begin{array}{c}\text { Dry plant wt } \\
(\mathrm{Mg} / \text { ha/year })\end{array}$ & \multicolumn{1}{c}{ Reference } \\
\hline Desert grasslands & $2.00-3.00$ & Woodwell and Whittaker (1968) \\
Desert grasslands & $2.25-3.79$ & Sims and Singh (1978) \\
Mountain grassland & $8.00-9.20$ & Sims and Singh (1978) \\
Shortgrass prairies & $5.70-13.00$ & Sims and Singh (1978) \\
Mixed prairies & $5.20-14.25$ & Sims and Singh (1978) \\
Tallgrass prairie & $7.00-13.53$ & Sims and Singh (1978) \\
Tallgrass prairie & $9.92-11.32$ & Kucera et al. (1967) \\
Tropical grasslands & $2.00-20.00$ & Leith (1975) \\
Tropical grasslands & $15.00-30.00$ & Woodwell and Whittaker (1968) \\
Temperate grassland & 6.76 & Van Hook (1971) \\
Temperate grasslands & $1.00-15.00$ & Leith (1975) \\
Average biomass & $5.89 \pm 1.26^{\mathrm{z}}$ to $12.71 \pm 2.30^{\mathrm{z}}$ & \\
\hline
\end{tabular}

zThe mean of each range is followed by the SE.

Table 3. Annual soil organic carbon accumulation rates of grasslands in the United States.

\begin{tabular}{lcc}
\hline Land use/management & $\begin{array}{c}\text { Avg SOC accumulation } \\
(\mathrm{Mg} \mathrm{C} / \text { ha/year })\end{array}$ & References \\
\hline Cultivated reseeded to grass & 0.80 & Bruce et al. (1999) \\
Low-high grassland management & 0.54 & Contant et al. (2001) \\
Cultivated to wheatgrass & 0.189 & White et al. (1976) \\
Cultivated to Russian wild rye & 0.069 & White et al. (1976) \\
Cultivated to abandoned grassland & 0.031 & Burke et al. (1995) \\
Cultivated to perennial grasslands & 1.10 & Gebhart et al. (1994) \\
Average SOC accumulation & $0.46 \pm 0.18^{\mathrm{z}}$ & \\
\hline
\end{tabular}

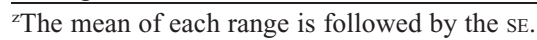

$\mathrm{SOC}=$ soil organic carbon; $\mathrm{C}=$ carbon.

Puget et al., 2005; Schimel et al., 1994). This is the amount of plant material left as SOC after detrital and microbial turnover (Schimel et al., 1994). Thus, the rate of SOC sequestration was estimated at 0.6 to $1.3 \mathrm{Mg} \mathrm{C} / \mathrm{ha} /$ year after adjusting for the humification efficiency.

Data on SOC sequestration included U.S. grasslands and lands converted to grasslands or turfgrass (Table 3 ). The sites chosen ranged widely in geography and climate across the United States. The data on SOC sequestration consisted of direct soil measurements or a combination of direct soil measurements and modeling techniques. SOC sequestration rates in grassland and prairie sites were similar to those from perennial turfgrass systems found in the literature (Pouyat et al., 2002; Qian and Follett, 2002). The average rate of SOC sequestration was $0.46 \mathrm{Mg} \mathrm{C} /$ ha/year (Table 3).

Soil organic carbon sequestration models are often developed using the NPP data (Smith et al., 2008). The present model uses NPP and SOC dynamic studies for grasslands specifically selected to compare two different approaches. Both NPP and SOC sequestration rates are comparable and support the conclusion that SOC sequestration values obtained could be representative of U.S. home lawns. The average rate of SOC sequestration ranged from 0.5 to $1.3 \mathrm{Mg} \mathrm{C} / \mathrm{ha} /$ year for the United States (Tables 2 and 3), equivalent to 46.0 to $127.1 \mathrm{~g}$ $\mathrm{C} / \mathrm{m}^{2} /$ year.

Influence of fertilizer and irrigation on soil organic carbon sequestration. Fertilizer and irrigation practices can increase the SOC pool by increasing the amount of biomass production (Lal et al., 1999). The proposed model uses experimental data relating the rate of biomass production to $\mathrm{N}$ application. Grasslands receiving fertilizer produced $7 \%$ to $298 \%$ more dry biomass than unfertilized grassland (Beaty et al., 1960; Graber and Ream, 1931;
Harrison, 1934; Juska et al., 1955; Juska and Hanson, 1969; Lovvorn, 1945; Madison, 1961; Sullivan, 1961; Warnes and Newell, 1968). The rate of increase in the SOC pool by irrigation is estimated at 50 to $100 \mathrm{~kg} \mathrm{C} / \mathrm{ha} /$ year, an equivalent of 5 to $10 \mathrm{~g} \mathrm{C} / \mathrm{m}^{2} /$ year (Lal et al., 1999). Each set of SOC sequestration data is summed to attain the net cumulative SOC sequestration rate. Each term is expressed in units of $\mathrm{g} \mathrm{C} / \mathrm{m}^{2} /$ year (Eq. [2]).

$$
\begin{aligned}
& \text { Net SOC Sequestration rate }= \\
& \text { SOC by humification } \\
& + \text { Fertilizer SOC + Irrigation SOC }
\end{aligned}
$$

Hidden carbon costs. Lawn management practices of mowing, irrigating, fertilizing, and using pesticides are derived from energy-based inputs. The HCCs are the amount of energy expended by different lawn maintenance practices from manufacturing to the amount used in lawn care. The HCCs of turfgrass operations are not well documented. Therefore, farm operation energy conversions were used in this model. Turfgrass operations were assumed to be similar to farm land operations in terms gasoline emissions from maintenance equipment, supplemental irrigation, and fertilizer and pesticide production and transportation. Lal (2004b) converted energy use from farm operations into units of CEs expressed as $\mathrm{g} \mathrm{CE} /$ $\mathrm{m}^{2} /$ year. Inputs from turfgrass management practices are converted into kilograms $\mathrm{CE}$ and are summed for each maintenance practice to estimate the HCC (Eq. [3]).

$$
\begin{aligned}
\mathrm{HCC}= & \text { CE Mowing }+ \text { CE Irrigation } \\
& + \text { CE Fertilizer }+ \text { CE Pesticides }
\end{aligned}
$$

Hidden carbon costs of the inputs are used in the model to compute net SOC sequestration rates. The HCC of mowing is based on typical homeowner practices of mowing once per week from April to October for a total of 28 mowings/year (Augustin, 2007). The number of mowings is similar to a 900-person survey taken by students of Eastern Illinois University who found the average number of mowings was 30 times per year. However, the average in the university study was extremely variable as a result of the inclusion of other yard maintenance practices (Quigly, 2001). University 
recommendations for lawn management practices include leaving the clippings on the lawn after mowing (McKinley, 2005; Thurn et al., 1994). Recycling clippings is a common practice in a home lawn situation as a result of landfill restrictions on yard waste (Qian et al., 2003). Therefore, it is assumed homeowners leave clippings on the lawn after mowing.

Over $50 \%$ of homeowner lawnmowers are walk-behind with a 2.2 to 3.7 kilowatt gasolinepowered motor (Quigley, 2001). Mowers in this category consume 12.7 to $20.4 \mathrm{~mL}$ gasoline/min (Priest et al., 2000). The CE of gasoline developed by Lal (2004b) was a compilation of a wide range of fuel sources used in farm operations and averages $0.8 \mathrm{~g}$ $\mathrm{CE} / \mathrm{g}$ gasoline. Mowing time for an averagesized lawn is estimated at an average walking speed of $4.0 \mathrm{~km} \cdot \mathrm{h}^{-1}$ for mowing a $0.5 \mathrm{~m} \times$ $1509.5-\mathrm{m}$ (0.08 ha) strip and doubling the time for making mower turns (Tudor-Locke, 2003; Weil, 2009). Therefore, mowing produces 12.9 to $20.6 \mathrm{~g} \mathrm{CE} / \mathrm{m}^{2} /$ year. Riding mowers may emit more fuel than walk-behind mowers but take less time to mow. Therefore, this rate was standardized for all management levels.

Rates of turfgrass water use and evapotransporation (ET) are well established and vary among turfgrass species (Kenna, 2006). The rates of water use for turfgrasses range from 3.0 to $8.0 \mathrm{~mm} \cdot \mathrm{d}^{-1}$ and of ET from 3.0 to 12.0 $\mathrm{mm} \cdot \mathrm{d}^{-1}$ (Beard, 1973; Kenna, 2006). In general, BMPs suggest irrigating turfgrass when rainfall volume is less than that of ET (McKindey, 2005; Osmond and Bruneau, 1999; Thurn et al., 1994; Trenholm et al., 2002).

In areas of the United States receiving enough rainfall to supply water to the grass, lawns can survive without any irrigation (Bormann et al., 1993). In arid areas of the United States, irrigation may be required for turfgrass survival (Bormann et al., 1993). The $\mathrm{CE}$ of irrigation was derived from the amount of energy required to pump water and is variable as a result of the difference in system pressure, water lift, pipe friction, water flow rate, and efficiency (Lal, 2004b). The majority of homeowners participating in irrigation practices use hose-end sprinklers (Powell and Witt, 2003). Therefore, the hand-moved sprinkler conversion from farm operations was used and consisted of $1.6 \mathrm{~g} \mathrm{CE} / \mathrm{m}^{2} /$ year (Lal, 2004b).

The CE conversions for fertilizers and pesticides were derived from a compilation of production, packaging, storage, and distribution requirements for fertilizer and pesticide a.i. (Lal, 2004b) and vary based on the lawn management category. The CE conversion of fertilizer was 0.9 to $1.8 \mathrm{~g} \mathrm{CE} / \mathrm{g}$ nitrogen, 0.1 to $0.3 \mathrm{~g} \mathrm{CE} / \mathrm{g}$ of phosphorus, and 0.1 to $0.2 \mathrm{~g} \mathrm{CE} /$ $\mathrm{g}$ of potassium (Lal, 2004b). The CE conversion for pesticides was 1.7 to $12.6 \mathrm{~g} \mathrm{CE} / \mathrm{g}$ herbicide and 1.2 to $8.1 \mathrm{~g} \mathrm{CE} / \mathrm{g}$ insecticide (Lal, 2004b).

\section{Results}

Minimal input management. Minimal input lawns, comprising of 40 million homes, are defined as mowing once a week without irrigation, fertilizer, or pesticide use (Augustin,
2007). The net SOC sequestration model for $\mathrm{MI}$ is based on the gross SOC minus the HCC.

The SOC sequestration rate was 46.0 to $127.1 \mathrm{~g} \mathrm{C} / \mathrm{m}^{2} /$ year (Table 2 and 3). Carbon equivalents for mowing, used to estimate the total HCC for MI, were 12.9 to $20.6 \mathrm{~g} \mathrm{CE} / \mathrm{m}^{2} /$ year. Thus, total net SOC sequestration rate per MI home lawn was 25.4 to $114.2 \mathrm{~g} \mathrm{C} / \mathrm{m}^{2} /$ year (Table 4) or a total of 0.8 to 3.6 Teragrams $(\mathrm{Tg}) /$ year for the United States.

Do-it-yourself management. The rate of SOC sequestration per DIY home lawn was 46.0 to $127.1 \mathrm{~g} \mathrm{C} / \mathrm{m}^{2} /$ year (Tables 2 and 3). The rate of SOC sequestration from nitrogen $(\mathrm{N})$ fertilization was based on $2.63 \times 10^{5} \mathrm{Mg}$ of $\mathrm{N} /$ year applied to all DIY lawns divided by 30 million lawns. Thus, DIY lawns apply $\approx 10.9 \mathrm{~g} \cdot \mathrm{m}^{2} /$ year $\mathrm{N}$ and produce an estimated $980 \mathrm{~g}$ biomass $/ \mathrm{m}^{2} /$ year (Beaty et al., 1960; Graber and Ream, 1931; Harrison, 1934; Juska et al., 1955; Juska and Hanson, 1969; Lovvorn, 1945; Madison, 1961; Sullivan, 1961; Warnes and Newell, 1968). The rate of biomass produced in a DIY lawn was $780 \mathrm{~g} / \mathrm{m}^{2} /$ year more than unfertilized lawns (Beaty et al., 1960; Graber and Ream, 1931; Harrison, 1934; Juska et al., 1955; Juska and Hanson, 1969; Lovvorn, 1945; Madison, 1961; Sullivan, 1961; Warnes and Newell, 1968). After accounting for humification efficacy, the rate of SOC sequestration in each DIY lawn was $78.0 \mathrm{~g} \mathrm{C} / \mathrm{m}^{2} /$ year from fertilization.

Only $10 \%$ to $15 \%$ (3 to 4.5 million) of DIY lawns irrigate (National Agriculture Statistics Service, 2002, 2004), and the rate of SOC sequestration aided by irrigation was 5 to $10 \mathrm{~g}$ of $\mathrm{C} / \mathrm{m}^{2} /$ year (Lal, 2004b). Therefore, total SOC sequestration for 3 to 4.5 million irrigated home lawns was 12,000 to $36,000 \mathrm{Mg} \mathrm{C}$ /year.

The CE values for mowing, irrigating, and applying fertilizers and pesticides were summed to obtain the total HCC for DIY. The CE for mowing was 12.9 to $20.6 \mathrm{~g} \mathrm{CE} / \mathrm{m}^{2} /$ year and that for irrigation is an average of the $10 \%$ to $15 \%$ of the households that irrigate. The CE conversion for hand-moved sprinklers ( $16.3 \mathrm{~kg} \mathrm{CE} / \mathrm{ha} /$ year) was multiplied by 3 to 4.5 million home lawns. This total was divided by 30 million DIY lawns for an average of 0.1 to $0.3 \mathrm{~g} \mathrm{CE} / \mathrm{m}^{2} /$ year.

Fertilizer use for DIY lawns in the United States was $9.07 \times 10^{5} \mathrm{Mg}$ of fertilizer sold to the DIY category on a yearly basis (The Scotts Miracle-Gro Company, 2006). A typical lawn fertilizer analysis by weight is $29 \% \mathrm{~N}, 3 \%$ phosphorus $(\mathrm{P})$, and $4 \%$ potassium $(\mathrm{K})$ (The Scotts Miracle-Gro Company, 2006). This amounts to $2.63 \times 10^{5} \mathrm{Mg}$ of N/year, $2.70 \times$ $10^{4} \mathrm{Mg}$ of $\mathrm{P} /$ year, and $3.60 \times 10^{4} \mathrm{Mg}$ of $\mathrm{K} /$ year. The CE conversions for fertilizer $(0.9$ to $1.8 \mathrm{~g}$ $\mathrm{CE} / \mathrm{g} \mathrm{N}, 0.1$ to $0.3 \mathrm{~g} \mathrm{CE} / \mathrm{g}$ of $\mathrm{P}$, and 0.1 to $0.2 \mathrm{~g}$ $\mathrm{CE} / \mathrm{g}$ of $\mathrm{K}$ ) were multiplied by the appropriate fertilizer component to obtain an average of 10.1 to $20.4 \mathrm{~g} \mathrm{CE} / \mathrm{m}^{2} /$ year.

Pesticide use for the lawn and garden category in the United States is estimated at 11,800 $\mathrm{Mg}$ herbicides and 2,800 Mg insecticides/year (United States Environmental Protection Agency, 2004). Because this report includes lawns, gardens, landscaping beds, pesticides used indoors, and pesticides used on pets, the pesticide rate was assumed to be divided among the categories. Therefore, it was assumed half of the consumption was on lawns and the other half was on landscape, garden, indoor, and pet pesticides. This number also fell in the same range as proprietary sales data given by The Scotts Miracle-Gro Company. Therefore, lawn herbicides are estimated at $5900 \mathrm{Mg}$ / year and pesticides at $1400 \mathrm{Mg} /$ year. The CE conversion for pesticide a.i. (1.7 to $12.6 \mathrm{~g} \mathrm{CE} / \mathrm{g}$ herbicide and 1.2 to $8.1 \mathrm{~g} \mathrm{CE} / \mathrm{g}$ insecticide) was divided among the 30 million DIY lawns for an average of 0.4 to $2.6 \mathrm{~g} \mathrm{CE} / \mathrm{m}^{2} /$ year.

The gross SOC sequestration for the average DIY lawn was 124.5 to $206.6 \mathrm{~g} \mathrm{C} / \mathrm{m}^{2} /$ year with a $\mathrm{HCC}$ of 23.6 to $43.9 \mathrm{~g} \mathrm{CE} / \mathrm{m}^{2} /$ year. Thus, the total net SOC sequestration rate for a DIY home lawn was 80.6 to $183.0 \mathrm{~g} \mathrm{C} / \mathrm{m}^{2} /$ year (Table 4 ) or at total of 1.9 to $4.4 \mathrm{Tg} /$ year for the United States.

Best management practices. Home lawns following BMPs are comprised of 10 million homes, which use a lawn care service or engage in multiple fertilizer applications in a given year (Augustin, 2007). Lawn care services adopt university BMPs as a management program. This program is defined as mowing once per week, fertilizing four times a year with pest prevention, and irrigating regularly when rainfall is insufficient for healthy grass growth (Carrow et al., 2001; Fipps et al., 2005; Heckman and Murphy, 2003; Landschoot, 2005; Louisiana State University, 2008; McKinley, 2005; Osmond and Bruneau, 1999; Reicher and Throssell, 1998; Rieke and Lyman, 2002; Sartain, 2000; Street and White, 2006; Thurn et al., 1994; Trenholm et al.,

Table 4. U.S. grassland annual soil organic carbon accumulation rate.

\begin{tabular}{|c|c|c|c|}
\hline & Minimal input lawns & Do-it-yourself lawns & $\begin{array}{c}\text { Best management } \\
\text { practices lawns }\end{array}$ \\
\hline & \multicolumn{3}{|c|}{ 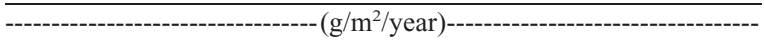 } \\
\hline$\overline{\mathrm{SOC}}$ & $46.0-127.1$ & $46.0-127.1$ & $46.0-127.1$ \\
\hline Fertilizer SOC & 0 & 78.0 & $78.0-98.0$ \\
\hline Irrigation SOC & 0 & $0.5-1.5$ & $5.0-10.0$ \\
\hline Gross SOC & $46.0-127.1$ & $124.5-206.6$ & $129.0-235.1$ \\
\hline Mowing $\mathrm{HCC}$ & $12.9-20.6$ & $12.9-20.6$ & $12.9-20.6$ \\
\hline Irrigation $\mathrm{HCC}$ & 0 & $0.1-0.3$ & 1.6 \\
\hline Fertilizer HCC & 0 & $10.1-20.4$ & $15.5-49.5$ \\
\hline Pesticide HCC & 0 & $0.4-2.6$ & $0.8-5.6$ \\
\hline Gross HCC & $12.9-20.6$ & $23.6-43.9$ & $30.8-77.3$ \\
\hline Total net sequestration & $25.4-114.2$ & $80.6-183.0$ & $51.7-204.3$ \\
\hline Total net sequestration per lawn & $20,320-91,360$ & $64,480-146,400$ & $41,360-163,440$ \\
\hline
\end{tabular}

$\mathrm{SOC}=$ soil organic carbon; $\mathrm{HCC}=$ hidden carbon cost. 
2002). The net SOC sequestration model for BMPs was also based on subtracting the HCC from gross rate of SOC sequestration.

The rate of SOC sequestration was $80.0 \mathrm{~kg}$ C/lawn/year (Tables 2 and 3) based on industry standards of BMPs for fertilizing turfgrass 14.7 to $25.0 \mathrm{~g} \mathrm{~N} / \mathrm{m}^{2} /$ year (Carrow et al., 2001; Fipps et al., 2005; Heckman and Murphy, 2003; Landschoot, 2005; Louisiana State University, 2008; McKinley, 2005; Osmond and Bruneau, 1999; Reicher and Throssell, 1998; Rieke and Lyman, 2002; Sartain, 2000; Street and White, 2006; Thurn et al., 1994; Trenholm et al., 2002; University of Florida, 2004). This range is based on regional area and species type variations. The BMP rate of fertilizer application produced 780 to 980 g more biomass $/ \mathrm{m}^{2} /$ year than unfertilized grass (Beaty et al., 1960; Graber and Ream, 1931; Harrison, 1934; Juska et al., 1955; Juska and Hanson, 1969; Lovvorn, 1945; Madison, 1961; Sullivan, 1961; Warnes and Newell, 1968). Accounting for 10\% humification efficiency, SOC sequestered through $\mathrm{BMP}$ rates of $\mathrm{N}$ fertilization was 78.0 to $98.0 \mathrm{~g}$ $\mathrm{C} / \mathrm{m}^{2} /$ year. The SOC sequestered from irrigation was calculated at 5.0 to $10.0 \mathrm{~g} \mathrm{C} / \mathrm{m}^{2} /$ year.

The CE for mowing, irrigating, and applying fertilizers and pesticides was summed to compute the total HCC for BMPs. The HCC was 12.9 to $20.6 \mathrm{~g} \mathrm{CE} / \mathrm{m}^{2} /$ year for mowing. It was assumed that irrigation was practiced by all BMP lawns. The total amount of land under irrigation for the BMP category was $0.8 \mathrm{Mha}$. Using the hand-moved sprinkler conversion, BMP lawns used $1.6 \mathrm{~g} \mathrm{CE} / \mathrm{m}^{2} /$ year for irrigation.

Fertilizer use as modeled from university recommendations was based on applying 14.7 to $25.0 \mathrm{~g} \mathrm{~N} / \mathrm{m}^{2} /$ year. A common lawn fertilizer ratio is 5-1-2. Therefore, $\mathrm{P}$ was calculated at 3.0 to $5.0 \mathrm{~g} \mathrm{P} / \mathrm{m}^{2} /$ year and $\mathrm{K}$ was calculated at 6.0 to $10.0 \mathrm{~g} \mathrm{~K} / \mathrm{m}^{2} /$ year. The amount of $\mathrm{N}, \mathrm{P}$, and $\mathrm{K}$ was multiplied by the appropriate fertilizer component $\mathrm{CE}$ for a total of 15.5 to $49.5 \mathrm{~g} \mathrm{CE} / \mathrm{m}^{2} /$ year.

Pesticide use for BMPs is modeled on the basis of one application for each pre-emergence herbicide, post-emergence herbicide, and insect control per year (Louisiana State University, 2008; McKinley, 2005). All pesticide controls were based on common lawn granular fertilizer plus pest control combination products using percent a.i. of each pesticide (Scotts Training Institute, 2007). The pre-emergence control involved use of pendimethalin $\left(\mathrm{C}_{13} \mathrm{H}_{19} \mathrm{~N}_{3} \mathrm{O}_{4}\right)$ at a rate of $0.17 \mathrm{~g} \cdot \mathrm{m}^{-2}$. The post-emergence control involved a combination of 2,4-dichlorophenoxyyacetic acid $\left(\mathrm{C}_{8} \mathrm{H}_{6} \mathrm{Cl}_{2} \mathrm{O}_{3}\right)$ at $0.17 \mathrm{~g} \cdot \mathrm{m}^{-2}$ and Mecoprop- $\mathrm{P}\left(\mathrm{C}_{10} \mathrm{H}_{11} \mathrm{ClO}_{3}\right)$ at $0.08 \mathrm{~g} \cdot \mathrm{m}^{-2}$. Insect control involved the insecticide bifenthrin $\left(\mathrm{C}_{23} \mathrm{H}_{22} \mathrm{ClF}_{3} \mathrm{O}_{2}\right)$ at $0.01 \mathrm{~g} \cdot \mathrm{m}^{-2}$. Using the $\mathrm{CE}$ conversion for herbicide (1.70 to $12.60 \mathrm{~g} \mathrm{CE} / \mathrm{g}$ herbicide) and insecticide (1.2 to $8.1 \mathrm{~g} \mathrm{CE} / \mathrm{g}$ insecticide), the total amount of each pesticide was multiplied by the appropriate pesticide CE for a total of 0.8 to $5.6 \mathrm{~g} \mathrm{CE} / \mathrm{m}^{2} /$ year.

The average BMP home lawn has a gross SOC sequestration rate of 129.0 to $235.1 \mathrm{~g} \mathrm{C} /$ $\mathrm{m}^{2} /$ year, HCC of 30.8 to $77.3 \mathrm{~g} \mathrm{CE} / \mathrm{m}^{2} /$ year, and net SOC sequestration rate of 51.7 to 96.3 $\mathrm{g} \mathrm{C} / \mathrm{m}^{2} /$ year (Table 4 ) or a total of 0.4 to $0.8 \mathrm{Tg}$ / year for the United States.

\section{Discussion}

The proposed model is a national scale assessment of the net SOC sequestration potential of existing home lawns in the United States. The model indicated the rates of SOC sequestration estimated from NPP compare well with those from grassland and turfgrass SOC sequestration rates reported in published data. These rates are also similar to some cropland ecosystems. The rates of SOC sequestration are similar to the national average rates for other land uses.

An average size home lawn in the United States has the potential to sequester 20.3 to $163.4 \mathrm{~kg} \mathrm{C} / \mathrm{lawn} /$ year (Table 4). The largest increase in $\mathrm{C}$ sequestration occurs when management practices increase from MI to DIY. BMPs can increase the rate of SOC sequestration even further. At a high level of management, however, the HCC can offset the benefit of $\mathrm{C}$ sequestration. For example, a lawn in the arid southwest under a BMP lawn program has more HCC and a lower net rate of SOC sequestration. In contrast, a lawn in the northeast under a DIY program requires less $\mathrm{HCC}$ to maintain a healthy lawn and has a higher rate of SOC sequestration.

Total single-family home lawn area of 6.4 Mha covers $\approx 5 \%$ of the total land under cropland (138 Mha) in the United States (United States Census Bureau, 2010). From the model, the rate of SOC sequestered in home lawns is 0.5 to $1.5 \mathrm{Mg} \mathrm{C} /$ ha/year, which is more than an average rate for U.S. cropland of $0.3 \mathrm{Mg} \mathrm{C} / \mathrm{ha} /$ year (Lal and Follett, 2009). The rate of SOC sequestration for home lawns also falls in a rate similar to that for the world grasslands of 0.6 to $1.9 \mathrm{Mg} \mathrm{C} /$ ha/year (Bruce et al., 1999).

The rate of SOC sequestration depends on the antecedent SOC level, climate, profile characteristics, and management (Lal et al., 1999). The net rate of SOC sequestration for a specific land use (i.e., home lawns) eventually attains a steady state and the net rate approaches zero (Lal et al., 1999). The point of SOC saturation for home lawns is unknown and may vary widely among regions. Historical soil data on home lawns is limited as a result of the lack of continuity of lawn care maintenance practices.

The scope of the model can be further broadened to account for specific climate, soil types, lawn management practices, and soil gas flux. Validation through long-term field sampling of SOC is needed to determine the extent and limits to which urban lawn soils can sequester C. Direct measurements and future research will increase the precision and accuracy of this model to a local or regional scale.

\section{Literature Cited}

Augustin, B.J. 2007. Perception vs. reality: How much nitrogen do homeowners put on their lawn. Am. Soc. of Agron. 269-6 (abstr.).

Baird, J.H., N.T. Basta, R.L. Huhnke, G.V. Johnson, M.E. Payton, D.E. Storm, C.A. Wilson, M.D. Smolen, D.L. Martin, and J.T. Cole. 2000. Best management practices to reduce pesticide and nutrient runoff from turf, p. 268-293. In: Clark, J.M. and M.P. Kenna (eds.). Fate and management of turfgrass chemicals. Am. Chem. Soc. Symp. Ser. 743, Washington, DC.

Bandaranayake, W., Y.L. Quian, W.J. Parton, D.S. Ojima, and R.F. Follet. 2003. Estimation of soil organic carbon changes in turfgrass systems using the CENTURY model. Agron. J. 95:558-563.

Beard, J.B. 1973. The turfgrass environment, $p$. 179-380. In: Turfgrass science and culture. Prentice Hall, Englewood Cliffs, NJ.

Beaty, E.R., R.A. McCreery, and J.D. Powell 1960. Responses of Pensacola Bahiagrass to nitrogen fertilization. Agron. J. 52:453-455.

Blanco-Canqui, H. and R. Lal. 2004. Mechanisms of carbon sequestration in soil aggregates. Crit. Rev. Plant Sci. 23:481-504.

Bormann, F.H., D. Balmori, and G.T. Geballe. 1993. Redesigning the American lawn. Yale University Press, New Haven, CT, and London, UK.

Bruce, J.P., M. Frome, E. Haites, H. Janzen, R. Lal, and K. Paustian. 1999. Carbon sequestration in soils. J. Soil Water Conserv. 54:382-390.

Burke, I.C., W.K. Lauenroth, and D.P. Coffin. 1995. Soil organic matter recovery in semiarid grasslands: Implications for the Conservation Reserve Program. Ecol. Monogr. 5:793-801.

Campbell, C.A. and R.P. Zenter. 1993. Soil organic matter as influenced by crop rotation and fertilization. Soil Sci. Soc. Amer. J. 57:1034-1040.

Carrow, R.N., D.V. Waddington, and P.E. Rieke. 2001. Developing fertilizer programs, p. 339346. In: Turfgrass soil fertility and chemical problems Wiley, Hoboken, NJ.

Contant, R.T., K. Paustian, and E.T. Elliott. 2001. Grassland management and conversion into grassland: Effects on soil carbon. Appl. Ecol. 11:343-355.

Duiker, S. and R. Lal. 2000. Carbon budget study using $\mathrm{CO}_{2}$ flux measurements from a no-till system in central Ohio. Soil Tillage Res. 54:21-30.

Eichner, M.J. 1990. Nitrous oxide emissions from fertilized soils: Summary of available data. J. Environ. Qual. 19:272-280.

Falk, J.H. 1976. Energetics of a suburban lawn ecosystem. Ecology 57:141-150.

Falk, J.H. 1980. The primary productivity of lawns in an urban environment. J. Appl. Ecol. 17:689-696.

Fipps, G., J. McAfee, and D. Smith. 2005. Turf irrigation and nutrient management reference manual. Texas A\&M Coop. Ext. Bul. B-6165.

Follett, R.F., G.E. Varvel, J.M. Kimble, and K.P. Vogal. 2009. No-Till corn after bromegrass: Effect on soil carbon and soil aggregates. Agron. J. 101:261-268.

Foth, H.D. and B.G. Ellis. 1997. Soil fertility. 2nd Ed. CRC Press, Inc., Boca Raton, FL.

Gebhart, D.L., H.B. Johnson, H.S. Mayeux, and H.W Polley. 1994. The CRP increases soil organic carbon. J. Soil Water Conserv. 49:488-492.

Glendining, M.J. and D.S. Powlson. 1991. The effect of long-term applications of inorganic nitrogen fertilizer on soil organic nitrogen, $\mathrm{p}$. 329-338. In: Wilson, W.S. (ed.). Advances in soil organic matter research: The impact of agriculture and the environment Ambridge, UK.

Graber, L.F. and H.W. Ream. 1931. Growth of bluegrass with various defoliations and abundant nitrogen supply. J. Amer. Soc. Agron. 23:938-945.

Gregorich, E.G., B.H. Ellert, C.F. Drury, and B.C. Lang. 1996. Turnover of soil organic matter and storage of corn residue carbon estimated from natural ${ }^{13} \mathrm{C}$ abundance. Can. J. Soil Sci. 60:161-167.

Groffman, P.M., C.O. Williams, R.V. Pouyat, L.E Band, and I.D. Yesilonis. 2009. Nitrate leaching and nitrous oxide flux in urban forests and grasslands. J. Environ. Qual. 38:1848-1860.

Grounds Maintenance. 1996. Turf acrage. Grounds Maint. 31:10. 
Harrison, C.M. 1934. Responses of Kentucky bluegrass to variations in temperature, light, cutting, and fertilizing. Agron. J. 9:83-106.

Heckman, J. and J. Murphy. 2003. Fertilizing the home lawn. Rutgers Coop. Res. and Ext. Bul. FS633.

Intergovernmental Panel on Climate Change. 2001. Climate change 2001-The scientific basis. Contribution of working group I to the third assessment report of the intergovernmental panel on climate change. In: Houghton, J.T., Y. Ding, D.J. Griggs, M. Noguer, P.J. Van derLinden, X. Dai, K. Maskell, and C.A. Johnson (eds.). Cambridge University Press, Cambridge, UK.

Janssen, I.A., E.D. Schulze, S. Luyssaert, P. Ciais, and A. Freibauer. 2009. Importance of methane and nitrous oxide for Europe's terrestrial greenhouse-gas balance. Nat. Geosci. 2:842-850.

Juska, F.V. and A.A. Hanson. 1969. Nutritional requirements of Роа аппиа L. Agron. J. 61:466468.

Juska, F.V., J. Tyson, and C.M. Harrison. 1955. The competitive relationship of merion bluegrass as influenced by various mixtures, cutting heights, and levels of nitrogen. Agron. J. 47:513-518.

Kaye, J.P., I.C. Burke, A.R. Mosier, and J.P. Guerschman. 2004. Methane and nitrous oxide fluxes from urban soils to the atmosphere. Ecol. Appl. 14:975-981.

Kaye, J.P., R.L. McCulley, and I.C. Burke. 2005. Carbon fluxes, nitrogen cycling, and soil microbial communities in adjacent urban, native and agricultural ecosystems. Glob. Change Biol. 11:575-587.

Kenna, M.P. 2006. Turfgrass and the environment, p. 65-90. In: Beard, J.B. and M.P. Kenna (eds.). Water quality and quantity issues for turfgrasses in urban landscapes. Council for Agr. Sci. and Tech Ames, IA.

Khan, S.A., T.R. Mulvaney, T.R. Ellsworth, and C.W. Boast. 2007. The myth of nitrogen fertilization for soil carbon sequestration. J. Environ. Qual. 36:1821-1832.

Kucera, C.L., R.C. Dahlman, and M.R. Koelling. 1967. Total net productivity and turnover on an energy basis for tallgrass prairie. Ecology 48:1-24.

Lal, R. 2003. Offsetting global $\mathrm{CO}_{2}$ emissions by restoration of degraded and intensification of world agriculture and forestry. Land Degrad. and Dev. 14:309-322.

Lal, R. 2004a. Soil carbon sequestration to mitigate climate change. Geoderma 123:1-22.

Lal, R. 2004b. Carbon emissions from farm operations. Environ. Int. 30:981-990.

Lal, R. 2008. Promise and limitations of soils to minimize climate change. J. Soil Water Conserv. 63:113-118.

Lal, R. 2009. Sequestering atmospheric carbon dioxide. Crit. Rev. Plant Sci. 28:90-96.

Lal, R. and R. Follett. 2009. Soils and climate change, p. xxi-1. In: Lal, R. and R.F. Follett (eds.). Soil carbon sequestration and the greenhouse effect. 2nd Ed. Soil Sci. Soc. of Amer., Madison, WI.

Lal, R., R.F. Follet, J.M. Kimble, and C.V. Cole. 1999. Managing U.S. cropland to sequester carbon in soil. J. Soil Water Conserv. 54:374381.

Landschoot, P.J. 2005. Turfgrass fertilization basics. Penn. State Univ. Coop. Ext. University Park, PA, 4 Oct. 2005. <http://turfgrassmanagement. psu.edu/turfgrassfertilizationbasics.cfm>.

Leified, J. 2006. Soils as sources and sinks of greenhouse gases. Geological Soc. Special Pub. 266:23-44.

Leith, H. 1975. Primary productivity of the major vegetational units of the world, p. 203-216.
Leith, H. and R.H. Whittaker. Primary Productivity of the Bisphere. Springer, NY.

Lorenz, K. and R. Lal. 2009a. Carbon dynamics in urban soils, p. 393-400. In: Lal, R. and R.F. Follett (eds.). Soil carbon sequestration and the greenhouse effect. 2nd Ed. Soil Sci. Soc. of Amer., Madison, WI.

Lorenz, K. and R. Lal. 2009b. Biogeochemical C and $\mathrm{N}$ cycles in urban soils. Environ. Int. 35:1-8.

Louisiana State University. 2008. Louisiana lawns best management practices. Louisiana Agr. Ctr. Bul. 2940.

Lovvorn, R.L. 1945. The effect of defoliation, soil fertility, temperature, and length of day on the growth of some perennial grasses. J. Amer. Soc. Agron. 37:570-581.

Madison, J.H. 1961. Turfgrass ecology, effects of mowing, irrigation, and nitrogen treatments of Agrostis palustris Huds., 'Seaside' and Agrostis tenuis Sibth., 'Highland' on population, yield, rooting, and cover. Agron. J. 53:407-412.

Maggiotto, S.R., J.A. Webb, C. Wagner-Riddle, and G.W. Thurtell. 2000. Nitrous and nitrous oxide fluxes from turfgrass receiving different forms of nitrogen fertilizer. J. Environ. Qual. 29:621-630.

McKinley. 2005. Ortho's all about lawns. Meredith Books, Des Moines, IA.

Milesi, C., S.W. Running, C.D. Elvidge, J.B. Dietz, B.T. Tuttle, and R.R. Nemani. 2005. Mapping and modeling the biogeochemical cycling of turfgrasses in the United States. Environ. Manage. 36:426-438.

National Agricultural Statistics Service. 2002. Michigan turfgrass survey. Mich. Agric. Stat. Serv., Lansing, MI.

National Agricultural Statistics Service. 2004. New York Agric. Stat. Serv., Albany, NY.

National Association of Realtors. 2001. Land use and land loss in the United States: The impact of land use trends on real estate development. The Res. Div. of the Natl. Assn. of Realtors, Washington, D.C

National Gardening Association. 2004. Natl. gardening survey. Burlington, VT.

Neeta, S., C. Bijoor, I. Czimczik, and E. Pataki. 2008. Effects of temperature and fertilization on nitrogen cycling and community composition of an urban lawn. Glob. Change Biol. 14:2119-2131.

Nowak, D.J., M.H. Noble, S.M. Sisinni, and J.F. Dwyer. 2001. People and trees: Assessing the US urban forest resource. J. For. 99:37-42.

Nowak, D.J., R.A. Rowntree, E.G. McPherson, S.M. Sisinni, E.R. Kerkmann, and J.C. Stevens. 1996. Measuring and analyzing urban tree cover. Landsc. Urban Plan. 36:49-57.

Osmond, D.L., and A.H. Bruneau. 1999. Caring for your lawn and the environment. North Carolina State Coop. Ext. Publ. E99-35386.

Pataki, D.E., R.J. Alig, A.S. Fung, N.E. Golubiewski, C.A. Kennedy, E.G. McPherson, D.J. Norwalk, R.V. Pouyat, and P.R. Lankao. 2006. Urban ecosystems and the North American carbon cycle. Glob. Change Biol. 12:1-11.

Paustian, K., O. Andren, H. Janzen, R. Lal, P. Smith, G. Tian, H. Tiessen, M. Van Norrdwijk, and P. Woomer. 1997. Agricultural soil as a C sink to offset $\mathrm{CO}_{2}$ emissions. Soil Use Manage. 13:230244.

Petrovic, A.M. 1990. The fate of nitrogenous fertilizers applied to turfgrass. J. Environ. Qual. 19:1-14.

Phillips, R.L., D.L. Tanaka, D.W. Archer, and J.D. Hanson. 2009. Fertilizer application timing influences greenhouse gas fluxes over a growing season. J. Environ. Qual. 38:1569-1579.

Pickett, S.T.A., M.L. Cadenasso, J.M. Grove, P.M. Groffman, L.E. Band, C.G. Boone, and W.R. Burch, Jr., C.S.B. Grimmond, J. Hom, J.C.
Jenkins, N.L. Law, C.H. Nilon, R.V. Pouyat, K. Szlavecz, P.S. Warren, and M.A. Wilson. 2008 Beyond urban legends: An emerging framework of urban ecology, as illustrated by the Baltimore ecosystem study. Bioscience 58:1-12.

Post, W.M., C. Izaurralde, J.D. Jastrow, B.A. McCarl, J.E. Amonette, V.L. Bailey, P.M. Jardine, T.O. West, and J. Zhou. 2004. Enhancement of carbon sequestration in US soils. Bioscience 54:895-908.

Post, W.M. and K.C. Kwon. 2000. Soil carbon sequestration and land-use change: Processes and potential. Glob. Clim. Biol. 6:317-328.

Priest, M.W., D.J. Williams, and H.A. Brigman. 2000. Emissions from in-use lawn-mowers in Australia. Atmos. Environ. 34:657-664.

Pouyat, R., P. Groffman, I. Yesilonis, and L. Hernandez. 2002. Soil carbon pools and fluxes in urban ecosystems. Environ. Pollut. 116:S107S118.

Pouyat, R.V., I.D. Yesilonis, and D.J. Nowak. 2006. Carbon storage by urban soils in the USA. J. Environ. Qual. 35:1566-1575.

Powell, A.J. and M.L. Witt. 2003. Home lawn irrigation. Univ. of Kentucky College of Agr. Bul. ID-79

Puget, P., R. Lal, C. Izaurralde, M. Post, and L. Owens. 2005. Stock and distribution of total and corn-derived soil organic carbon in aggregate and primary particle fractions for different land use and soil management practices. Soil Sci. 170:256-279.

Qian, Y., W. Bandaranayake, W.J. Parton, B. Mecham, M.A. Harivandi, and A.R. Mosier. 2003. Long-term effects of clipping and nitrogen management in turfgrass on soil organic carbon and nitrogen dynamics: The CENTURY model simulation. J. Environ. Qual 32:1694-1700.

Qian, Y. and R.F. Follett. 2002. Assessing soil carbon sequestration in turfgrass systems using longterm soil testing data. Agron. J. 94:930-935.

Quigley, M.F. 2001. Ornamental plants annual reports and research reviews 2000. The Ohio State Univ. Special Circular 177-01.

Raciti, S.M., P.M. Groffman, and T.J. Fahey. 2008. Nitrogen retention in urban lawns and forests. Ecol. Appl. 18:1615-1626.

Reicher, Z. and C. Throssell. 1998. Fertilizing established lawns. Purdue Univ. Coop. Ext. Serv. Bul. AY-22.

Rickman, R.W., C.L. Douglas Jr., S.L. Albrech, L.G. Bundy, and J.L. Berc. 2001. CQUESTER: A model to estimate carbon sequestration in agricultural soils. J. Soil Water Conserv. 56: 237-243.

Rieke, P.E. and G.T. Lyman. 2002. Lawn fertilization. Mich. State Univ. Ext. Bul. E05TURF.

Sartain, J.B. 2000. General recommendations for fertilization of turfgrasses on Florida soils. Univ. of Florida Ext. Bul. SL21.

Schimel, D.S., B.H. Braswell, E.A. Holland, R. McKeown, D.S. Ojima, T.H. Painter, W.J. Parton, and A.R. Townsend. 1994. Climatic, edaphic, and biotic controls over storage and turnover of carbon in soils. Global Biogeochem. Cycles 8:279-293.

Scotts Training Institute. 2007. 2008 product guide. Marysville, $\mathrm{OH}$.

Selhorst, A.L. 2007. Carbon sequestration and emissions due to golf course turfgrass development and maintenance in central Ohio. Thesis, The Ohio State Univ. Columbus.

Sims, P.L. and J.S. Singh. 1978. The structure and function of ten western North American grasslands III. Net primary production, turnover, and efficiencies of energy capture and water use. J. Ecol. 66:573-597. 
Smith, P., P. Falloon, U. Franko, M. Korschens, R. Lal, K. Paustian, D. Powlson, V. Romanenkov, L. Shevtsova, and J. Smith. 2007a. Greenhouse gas mitigation potential in agricultural soils, $\mathrm{p}$. 227-236. In: Canadell, J.G., D.E. Pataki, and L.F. Pitelka (eds.). Terrestrial ecosystems in a changing world. Springer, Heidelberg, Germany.

Smith, R.D., D. Martino, Z. Cai, D. Gwery, H. Janzen, P. Kumar, B. McCarl, S. Ogle, F. O'Mara, C. Rice, B. Scholeo, and O. Sirotnko. 2007b. Agriculture, p. 499-532. In: Metz, B., O.R. Davidson, P.R. Boach, R. Dave, and L.A. Meyers (eds.). Contribution of working group III to the fourth assessment report of the Intergovernmental Panel on Climate Change. Cambridge University Press, Cambridge, UK.

Smith, P., C. Fang, J.J.C. Dawson, and J.B. Moncrieff. 2008. Impact of global warming on soil organic carbon. Adv. Agron. 97:1-43.

Smith, T.M., W.P. Cramer, R.K. Dixon, R. Leemans, R.P. Neilson, and A.M. Solomon. 1993. The global terrestrial carbon cycle. Water Air Soil Pollut. 70:19-37.

Snyder, C.S., T.W. Bruulsema, and T.L. Jensen. 2007. Greenhouse gas emissions from cropping systems and the influence of fertilizer management- $\mathrm{A}$ literature review. International Plant Nutrition Institute, Norcross, GA.

Street, J.R., and S.K. White. 2006. Fertilization of lawns. The Ohio State Univ. Ext. Fact Sheet HYG-4006.

Sullivan, E.F. 1961. Effects of soil reaction, clipping height, and nitrogen fertilization on the productivity of kentucky bluegrass sod transplants in pot culture. Agron. J. 53:261-263.

The Scotts Miracle-Gro Company. 2006. Corporate responsibility report: Product usage monitoring protocols. Marysville, $\mathrm{OH}$.

Thurn, M.C., N.W. Hummel, and A.M. Petrovic. 1994. Home lawn establishment and maintenance. Cornell Coop. Ext. Bul. 185.

Tinsdale, S.L., W.L. Nelson, and J.D. Beaton. 1985. Soil fertility and fertilizers. 4th Ed. Maccmillan Co., New York, NY.

Trenholm, L.E., E.F. Gilman, G.W. Knox, and R.J. Black. 2002. Fertilization and irrigation needs for Florida lawns and landscapes, Univ. of Florida Ext. Publ. ENH860.

Tudor-Locke, C. 2003. Watch your step: Pedometers and physical activity. Alberta Sport, Recreation, Parks, and the Wildlife Foundation, Edmonton, Alberta, Canada.

Quigly, M.F. 2001. Ornamental plants annual reports and research reviews 2000. The Ohio State Unvi. Special Circular 177-01.

United Nations. 2004a. World population monitoring 2003: Population, education, and development. United Nations Department of Economic and Social Affairs, Population Division, Washington, DC.

United Nations. 2004b. World urbanization prospects: The 2003 revision. United Nations Department of Economic and Social Affairs, Population Division, Washington, DC.

United States Census Bureau. 2010. Urban and rural population. 2 Jan. 2010. $<$ http://www. census.gov/population/censusdata/urpop0090. txt>.

United States Environmental Protection Agency. 2004. Pesticide Industry sales and usage 2000 and 2001 market estimates. Washington, DC.

University of Florida. 2004. Homeowner best management practices for the home lawn. Institute of Food and Agr. Sci. Publ. ENH979.

Van Hook, R.I. 1971. Energy and nutrient dynamics of a spider and orthopeteron populations in a grassland ecosystem. Ecol. Monogr. 41:1-26.

Vinlove, F.K. and R.F. Torla. 1995. Comparative estimations of U.S. home lawn area. J. Turfgrass Manag. 1:83-97.

Warnes, D.D. and L.C. Newell. 1968. Establishment and yield responses of warm-season grass strains to fertilization. Grass Establ. 11:235240.

Weil, R. 2004. Walking speed. MedicineNet. 6 Mar. 2009. <http://www.medicinenet.com/walking/ page $5 . \mathrm{htm}>$.

White, E.M., C.R. Crueger, and R.A. Moore. 1976. Changes in total nitrogen, organic matter, available $\mathrm{P}$, and bulk densities of a cultivated soil 8 years after tame pastures were established. Agron. J. 68:581-583.

Whitehead, D.C. and J. Tinsley. 2006. The biochemistry of humus formation. J. Sci. Food Agr. 14:849-857.

Woodwell, G.M. and R.H. Whittaker. 1968. Primary production in terrestrial ecosystems. Am. Zool. 8:19-30. 